\title{
GLOBALISASI DAN HAK ASASI MANUSIA (HAM): STUDI KASUS PELANGGARAN HAM DI MYANMAR
}

\author{
Verdinand Robertua \\ verdinand.robertua@gmail.com \\ Fakultas Ilmu Sosial dan Ilmu Politik Universitas Padjajaran, Bandung
}

\begin{abstract}
This article is a conceptual review focusing the interrelatedness of globalization and human rights. Myanmar governments has been accused of exploiting Myanmar's human rights and European governments has applied sanctions and condemnations toward Myanmar. The research question is how human rights value internalize to Myanmar in the context of globalization. To answer this question, the author used English School Theory pioneered by Hedley Bull and Barry Buzan. Since this is a value debate, three concepts of English School will be used as value comparison which are international order, pluralism and solidarism. Through comparative study of values, this article concluded that universalization of human rights through sanctions provoked resistance from ASEAN countries. National and local values of ASEAN countries such as sovereignty and order have balanced the human rights value. "ASEAN Way" is symbol of balanced interaction between global and local values. Coexistence, a key concept of English School, become a key concept relevant in discussing the interrelatedness of globalization and human rights in the context of Myanmar.
\end{abstract}

Keywords: Globalization, Human Rights, English School, Pluaralism, Solidarism, International Order, ASEAN, Myanmar

\begin{abstract}
Abstrak
Artikel ini merupakan kajian konseptual membahas keterkaitan antara fenomena globalisasi dan konsep hak asasi manusia melalui studi kasus pelanggaran HAM di Myanmar. Tindakan dan kebijakan Pemerintah Myanmar dianggap merampas hak asasi manusia Myanmar dan memicu kemarahan dan sanksi ekonomi dari Uni Eropa Eropa. Pertanyaan yang diangkat adalah bagaimana penyebaran nilai HAM dalam konteks globalisasi dengan studi kasus Myanmar. Untuk menjawab pertanyaan ini, penulis menggunakan teori English School of International Relation yang digagas oleh Hedley Bull dan Barry Buzan. Dalam melihat perdebatan nilai HAM ini, terdapat tiga konsep English School untuk menjadi studi perbandingan nilai yaitu tatanan internasional, pluralism dan solidarisme. Melalui studi perbandingan nilai ini, penulis berkesimpulan bahwa globalisasi nilai HAM melalui instrumen sanksi yang diterapkan Uni Eropa menghasilkan resistensi dari negara-negara ASEAN dan tercipta interaksi yang lebih berimbang dengan memperhatikan nilai-nilai yang diadopsi negaranegara ASEAN. Coexistence yang diajukan konsep pluralisme dalam bentuk "ASEAN Way" menjadi relevan dalam perdebatan nilai HAM di Myanmar.
\end{abstract}

Kata kunci: Globalisasi, Hak Asasi Manusia, English School, Pluralisme, Solidarisme, Tatanan Internasional, ASEAN, Myanmar

\section{Pendahuluan}

Hak asasi manusia (HAM) menjadi fenomena penting dalam hubungan internasional. Setelah Perang Dingin, HAM menjadi topik acuan baik bagi negara maju maupun negara berkembang dalam politik luar negerinya. Ditambah lagi dengan organisasi internasional seperti Perserikatan Bangsa-Bangsa (PBB) yang aktif mengkampanyekan nilai HAM dan mengadili pelaku pelanggaran HAM berat seperti di Kamboja (Khmer Rouge 
Tribunal) dan masalah genosida di Yugoslavia (International Criminal Tribunal for the Former Yugoslavia). Organisasi regional pun turut membangun mekanisme penegakan HAM seperti Uni Eropa dengan European Court of Justice dan ASEAN dengan ASEAN Inter-govermental Commission on Human Rights (AICHR). Selain negara, aktor baru pun bermunculan seperti organisasi masyarakat sipil dan media masa yang mendukung gerakan HAM ini.

Pembahasan sosialisasi HAM terkait erat dengan fenomena globalisasi. Perkembangan teknologi informasi dan komunikasi, kemajuan infrastruktur dan suprastruktur transportasi, serta peningkatan intensitas perdagangan dunia mempercepat sosialisasi HAM ke seluruh penjuru dunia. Interdependensi dan konektivitas menjadi karakter penting dan sebuah peristiwa dapat diketahui dari tempat yang sangat jauh dengan sangat cepat dan berbiaya murah. Kelaparan atau bencana alam di sebuah tempat dengan cepat ditolong oleh masyarakat dunia. Penyiksaan tahanan teroris di Guantanamo menimbulkan keprihatinan dari berbagai negara. Media sosial seperti Twitter dan Facebook membantu perjuangan masyarakat sipil menggulingkan Pemerintahan Hosni Mobarak pada tahun 2011.

Kedua fenomena ini berusaha dikaji dengan menggunakan studi kasus pelanggaran HAM di Myanmar. Pelanggaran HAM di Myanmar mendapat sorotan serius dari masyarakat internasional. Mempertimbangkan tindakanpenganiayaan etnik minoritas oleh junta militer Myanmar, Sidang Umum PBB tahun 1991 dan Komisi HAM PBB 1992 mengeluarkan resolusi mengutuk berbagai kasus penganiayaan etnik minoritas yang terjadi di Myanmar (Human Rights Watch, 1990). Bahkan, Uni Eropa dan Amerika Serikat mejatuhkan sanksi ekonomi dan militer kepada Myanmar. Berbagai organisasi masyarakat sipil mengklaim bahwa rejim junta Myanmar telah melakukan penyiksaaan kaum minoritas dan kelompok oposisi. Amnesty Internasional mempublikasikan laporan mengenai penyiksaan tahanan politik (Amnesty International, 2005). Human Rights Watch mempublikasikan laporan mengenai penggunaan anak-anak sebagai tentara (Human Rights Watch, 2002). Pada tahun 2007, ribuan masyarakat Myanmar yang terdiri atas biarawan, mahasiswa dan aktivis turun ke jalan memprotes kebijakan Pemerintah yang menaikkan harga bahan bakar dan ongkos transportasi. Demonstrasi ini direspons oleh militer dengan penggunaan kekerasan. ABC News memberitakan 13 orang meninggal (Percy, 2015). Revolusi Saffron ini memicu protes keras dari berbagai penjuru dunia.

Menariknya, penyebaran nilai HAM dan demokrasi menimbulkan penolakan dari beberapa pemimpin negara. HAM dan demokrasi dipersepsikan sebagai budaya Barat. Budaya baru ini dikenal dengan istilah "Amerikanisasi" karena erat kaitannya dengan gaya hidup masyarakat Amerika. Seringkali budaya baru ini berbenturan dengan budaya lokal seperti pernikahan sejenis, pornografi, porno aksi atau individualisme. Dalam konteks pelanggaran HAM di 
Myanmar, Lee Kuan Yew, mantan Perdana Menteri Singapura dan Suharto, mantan Presiden Indonesia mengatakan bahwa HAM adalah budaya Barat yang identik dengan kehidupan kekerasan dan asusila (Petersson, 2006). Tan Shwe juga mengatakan bahwa nilai HAM yang berlaku di Barat tidak selalu cocok dengan negara-negara Asia (Ibid). Singapura dan Indonesia adalah negara yang paling aktif menyuarakan ketidaksetujuan terhadap kebijakan sanksi Uni Eropa dan Amerika Serikat kepada Myanmar. Dengan latar belakang di atas, maka artikel ini akan mengangkat pertanyaan "Bagaimana penyebaran nilai HAM dalam konteks globalisasi dengan studi kasus Myanmar?"

\section{Kerangka Teori: English School of International Relation}

Artikel ini akan menggunakan teori English School of International Relation (ES). ES merujuk kepada pemikiran Hugo Grotius yang berpaham rasionalisme yang menekankan peran hukum, sejarah, dan filosofi. Pemikir klasik dalam ES adalah Hedley Bull, C.A.W Manning, Martin Wight, dan John Vincent. ES menjadi perspektif yang dominan pada tahun 1990-an karena menjadi alternatif kuat bagi realisme dan liberalisme. Tatanan internasional, konsep yang dikembangkan ES, menekankan kepada nilai-nilai kemasyarakatan dari hubungan internasional. Negara masih menjadi aktor utama dengan melibatkan aktor non-negara. Perdamaian dunia dan hak asasi manusia menjadi topik pembahasan dalam ES. Alasan penggunaan teori ini didasarkan kepada permasalahan yang diangkat artikel ini bersifat dilematis. Perdebatan mengenai universalisme HAM dan demokrasi secara tajam dibahas oleh ES. Teori HI lainnya seperti Realisme, Liberalisme dan Marxisme tidak cukup mampu membahas kompleksitas masalah HAM ini. Realisme akan berfokus kepada kontestasi kekuatan yang berkonflik, liberalisme menghasilkan penjelasan yang tipis dengan penekanan kepada ekonomi dan proses perubahan dan marxisme memberikan kritik tajam terhadap struktur internasional namun belum memberikan penyelesaian. ES dianggap sebagai teori yang mampu mengeksplorasi pemikiran-pemikiran yang bertentangan. Untuk membahas masalah pelanggaran HAM di Myanmar maka ada lima konsep yang akan digunakan yaitu konsep kedaulatan, tatanan internasional, pluralism, solidarisme dan masyarakat internasional.

\section{Konsep Tatanan Internasional}

Anarki menjadi titik awal analisa bagi ES. Pemikir ES berpendapat bahwa struktur hubungan internasional yang bersifat anarki dapat menghasilkan keteraturan, perdamaian dan kesejahteraan. Realisme, di lain pihak, melihat struktur anarki akan menimbulkan sikap agresifitas dan menghasilkan konflik dan perang. Liberalisme melihat bahwa struktur hubungan internasional dipenuhi oleh berbagai peraturan dan hukum yang mengatur perilaku negara. Bagi ES, anarki lebih condong didefinisikan sebagai ketiadaan pemerintah dunia dan hukum dunia. Kedaulatan dan kepentingan negara adalah sumber pedoman perilaku sistem namun meskipun demikian, ketiadaan pemerintahan dunia tidak selalu 
berujung kepada konflik, perang dan krisis. Pada tahun 1977, Hedley Bull menulis sebuah buku The Anarchical Society: A Study of Order in World Politics, sebuah buku yang menjadi pegangan utama bagi penstudi HI dan menjadi referensi kunci bagi ES. Dalam buku Bull ini, tertuang jelas bagaimana sebuah tatanan internasional bisa terbentuk meskipun struktur hubungan internasional adalah anarki. Ia menjelaskan bahwa seluruh negara memiliki kepentingan bersama untuk mencapai keempat tujuan yaitu (1) pengakuan kedaulatan negara, (2) penggunaan solusi non-kekerasan, (3) penghargaan hak kepemilikan dan (4) pelaksanaan perjanjian internasional. Pencapaian keempat tujuan ini akan menghasilkan sebuah kondisi yang dinamakan tatanan internasional (international order) (Bull, 1977). Negara memiliki beberapa instrumen penting dalam mencapai tatanan internasional yaitu (1) diplomasi, (2) perang, (3) perimbangan kekuatan dan (4) interaksi negara besar. Menarik disini bagaimana pemikir ES menggunakan perang untuk mencapai tatanan internasional sedangkan penggunaan cara nonkekerasan adalah salah satu unsur tatanan internasional. Mereka meyakini melalui perang adil (just war) yang akan dijelaskan pada sub-bab berikutnya.

Lebih jauh pemikir ES mengatakan bahwa interaksi negara telah melahirkan serangkaian kebiasaan dan peraturan yang menjadikan hubungan internasional sebagai sebuah komunitas yang tertib dan tertata. Tatanan dan ketertiban yang dibangun oleh negara berdasarkan kepada nilai, norma dan identitas tertentu yang disepakati dan dibangun sehingga menjadi sebuah tatanan dan ketertiban yang kokoh.

\section{Konsep Pluralisme dan Solidarisme}

Salah satu kontribusi utama pemikiran ES adalah peran nilai dan norma dalam hubungan internasional. Di setiap interaksi negara, baik itu dalam level bilateral, kawasan atau dunia, nilai dan norma akan selalu hadir dan berpengaruh terhadap perilaku negara. Menjadi pertanyaan adalah bentuk nilai dan norma yang sudah disepakati negara. Bagi Hedley Bull, kedaulatan negara, penggunaan cara non-kekerasan, penghormatan kepada perjanjian internasional dan perlindungan kepemilikan aset adalah nilai-nilai yang berlaku di setiap interaksi negara. Namun bagi Vincent dan Wheeler, nilai-nilai tersebut masih bersifat minimum dan masih ada beberapa nilai dan norma lainnya yang dipatuhi oleh negara seperti perlindungan lingkungan hidup, penghormatan hak asasi manusia, atau pelestarian kebudayaan lokal.

Solidarisme dan pluralisme adalah konsep yang diperkenalkan Hedley Bull dalam tulisannya "The Grotian Conception of International Society". Ia mengatakan bahwa solidarisme adalah teori yang menjelaskan perilaku negara yang mematuhi peraturan internasional dan pluralisme adalah teori yang tidak memiliki solidaritas seperti solidarisme namun mampu mematuhi nilai-nilai minimalis dalam hubungan internasional (Bull, 1966). Nilai minimal yang ada dalam hubungan internasional adalah menghindari kekerasan, pengakuan kedaulatan negara, penghormatan hak properti dan 
sakralitas perjanjian internasional. Di luar nilai-nilai ini menjadi pelengkap bagi sebuah international society yang dimiliki solidarisme. Mayall menambahkan bahwa solidarisme berkaitan erat dengan solidaritas manusia dan diplomasi adalah alat untuk menjadikan solidaritas ini menjadi kenyataan.

Pluralisme melihat sistem hubungan internasional terdiri atas berbagai negara yang memiliki karakter yang berbeda-beda namun dapat hidup berdampingan dengan damai (coexistence). Beberapa negara memiliki sistem politik sosialis komunis dan beberapa negara memiliki sistem politik demokrasi liberal. Ada yang menggunakan sistem ekonomi tertutup seperti Korea Utara namun ada juga yang menggunakan sistem ekonomi terbuka seperti Amerika Serikat. Coexistence dapat terjadi karena nilai-nilai yang disepakati seminimal mungkin dan mencegah eskalasi nilai minimum yang tidak disepakati oleh komunitas negara. Hukum internasional bertugas untuk memastikan pelaksanaan nilainilai minimum ini dan mencegah ambiguitas dari nilai minimum yang sudah disepakati. Bagi pluralis, nilainilai HAM dapat terlaksana apabila nilai minimum sudah terlaksana dan mendapat kesepakatan luas dari berbagai negara. Subjek utama dalam hukum internasional adalah negara, bukan individu. Apabila menerapkan sistem hak dan kewajiban dengan subjek negara dan individu maka kekacauan akan terjadi. Oleh karena itu, pluralis mendukung konsep nonintervensi dimana negara yang memiliki kewajiban dan hak untuk menyelesaikan masalah rakyatnya.
Intervensi kemanusiaan dapat terjadi hanya apabila didukung oleh mayoritas luas dari negara-negara dan diimplementasikan dengan efektif.

Intervensi menjadi kajian khusus dalam pemikiran ES. Bagi penganut pluralis, intervensi harus semaksimal mungkin dihindari karena menganggu tatanan internasional. Bagi penganut solidaris, intervensi harus dilakukan untuk memastikan nilai-nilai bersama dipatuhi dan ditaati. Nick Wheeler adalah seorang solidaris dan menulis buku "Saving Strangers: Humanitarian Intervention in International Society". Menurut Wheeler, intervensi negara merupakan simbol perlawanan dari kelompok aktivis terhadap struktur hubungan internasional yang anarki dan menekankan kedaulatan negara (Wheeler, 2000). Keberadaan Dewan Keamanan PBB yang dapat menggunakan kekuatan militer untuk menyelesaikan masalah internal sebuah negara membuat posisi negara menjadi tidak bebas untuk melaksanakan kebijakannya. Kedaulatan negara ini seringkali dipakai untuk kepentingan penguasa dan tidak dipertanggungjawabkan kepada rakyat. Intervensi negara harus dilakukan ketika satu-satunya kebijakan yang dapat memperbaiki kondisi tersebut adalah intervensi negara.

Globalisasi membatasi gerak negara. Akses informasi yang begitu mudah dan keberadaan pemain baru membuat negara harus berpikir panjang sebelum bertindak. Sebelum kelahiran media sosial seperti Facebook dan Twitter, kelaparan yang terjadi di Tiongkok tidak akan direspons oleh negara lain. Apabila terjadi protes massal di Tiongkok saat ini maka 
seluruh dunia akan mengawasi respons Pemerintah Tiongkok. Keterlibatan organisasi masyarakat sipil (OMS) dalam berbagai perundingan internasional adalah bukti nyata negara harus memperhatikan aspirasi OMS dalam kebijakan domestik dan luar negeri. Bahkan, OMS dapat menekan negara agar mengikuti kehendak mereka karena kekuatan jaringan OMS yang menyebar di seluruh dunia. Belum lagi, kekuatan OMS ini didukung sumber daya finansial dari sumbangan donor yang berasal dari seluruh dunia.

Globalisasi membuat masyarakat dunia menjadi homogen (Buzan, 2004). Dalam buku Barry Buzan "From International to World Society: English School Theory and Social Structure of Globalisation", ia menekankan bahwa globalisasi memberikan ruang sangat besar untuk individu untuk melakukan komunikasi lintas batas dan ruang tersebut menjadi forum penyebaran nilai. Keberhasilan komunikasi ini akan menghasilkan konvergensi nilai dan homogenisasi. Kedua konsep ini sangat penting bagi Buzan karena masyarakat dunia memiliki konsep nilai yang jelas dan tegas yang akan dipatuhi oleh negara. HAM dan demokrasi dapat menjadi contoh bagaimana masyarakat dunia menjadikan kedua nilai tersebut nilai universal karena proses penyebaran melalui globalisasi. Akibatnya, agresivitas negara dapat diredam dan konflik menjadi sulit terpikirkan. Bahkan, negara akan menjadi aktor promotor nilai-nilai baru yang disebar melalui globalisasi ini. Keinginan masyarakat untuk menjadi masyarakat homogen artinya tidak ada lagi perbedaan antara masyarakat antar bangsa.

\section{Pembahasan: Pelanggaran HAM Sistematis di Myanmar}

Sejak merdeka tahun 1948, pemerintahan Myanmar harus menghadapi pemberontakan dari berbagai kelompok etnis minoritas. Pada tahun 1989, sudah 17 kelompok etnis yang memilih untuk berdamai dengan pemerintahan Myanmar. Namun masih ada beberapa kelompok etnis minoritas sepe rti etnis Shan, Chin, Arakan, dan Karen yang melakukan perlawanan terhadap pemerintah karena merasa tidak puas dengan tawaran dari pemerintah Myanmar. Dengan alasan ancaman disintegrasi Myanmar, junta militer menggunakan instrumen kekerasan untuk menumpas pemberontakan separatis etnik minoritas ini. Sejak tahun 1996, lebih dari 2.500 kampung yang dicurigai sebagai tempat tinggal pemberontak dibakar dan dibumihanguskan (Thomson, 1995). Diperkirakan sekitar 600.000 hingga satu juta penduduk diusir oleh tentara dari area-area yang dicurigai sebagai markas separatis etnik minoritas. Tindakan kekerasan terhadap kelompok minoritas ini mengakibatkan pengungsian besar-besaran ke negaranegara tetangga. Sejak awal dekade 1990-an tercatat lebih dari 100.000 etnis minoritas Karen, Karenni, Shan, dan Mon,telah mengung si ke Thailand. Pun, pada tahun 1992, sekitar 250.000 Komunitas muslim Burma dari kelompok Rohingnya yang tinggal di Negara Bagian Arakan mengungsi ke Bangladesh untuk menghindari tindak kekerasan kelompok Tatmadaw.

Pada tahun 1991 pihak junta meningkatkan serangan terhadap kelompok pemberontak minoritas seperti Karen National Union dan Kachin 
Independence Organization. Militer Myanmar merusak dan membakar semua rumah dan aset para pemberontak. Dalam beberapa kasus, militer Myanmarpun menggunakan penduduk sipil untuk menyerang para pemberontak ini. Mereka dijadikan "human mine sweepers". Banyak dari tentara sipil ini meninggal akibat kelelahan dan kekurangan makanan dan air. Lebih dari 100.000 pemberontak minoritas dilaporkan mengungsi ke perbatasan Cina setelah serangan brutal oleh junta militer.

Shan Women's Action Network (SWAN) dan Shan Human Rights Foundation (SHRF) melaporkan bahwa junta militer melakukan tindakan pemerkosaan perempuan sebagai senjata psikologis untuk melumpuhkan kelompok Shan, salah satu kelompok pemberontak. Dua lembaga ini mendokumentasikan 173 kasus pelecehan seksual yang melibatkan 52 batalion militer Myanmar dengan korban 625 ibu dan remaja perempuan (Thomson, 1995).

Penggunaan tenaga kerja paksa menjadi sesuatu yang endemik di Myanmar.Ketika junta militer membuka ekonominya untuk kedatangan investor asing, junta menggunakan 10.000 penduduk sipil dan tahanan penjara sebagai tenaga kerja paksa untuk membangun infrastruktur kota dan desa (Human Rights Watch, 2001). Para penduduk ini bekerja di dalam situasi yang sangat buruk dan rawan penyiksaan oleh aparat pemerintah. Minimnya minuman, makanan dan pengobatan mengakibatkan banyaknya tenaga kerja meninggal ketika sedang bekerja.
Amnesty

International

melaporkan bahwa dari Desember 1994 hingga Januari 1995, di negara bagian Arakan, dua belas orang tenaga kerja paksa meninggal karena mengalami penyakit demam yang tidak diobati (Amnesty International, 2005). Di daerah bagian utara sekitar 3.000 orang diambil dari Putao, negara bagian Kachin untuk dipaksa bekerja membangun jalan Putao-Sumprabum. Setelah berjalan kaki selama enam hari, mereka tidak mendapatkan pasokan makanan yang dijanjikan oleh junta militer. Banyak diantaranya meninggal karena menderita penyakit Malaria dan kelaparan. Selain karena tidak adanya makanan dan minuman, para tenaga kerja paksa juga rentan terhadap penyiksaan dan pemukulan oleh para pengawas. Seorang wanita dilaporkan meninggal dipukuli tentara karena berhenti bekerja untuk proyek pembangunan rel kereta api PakokkuKalemyo. Berdasarkan fakta-fakta ini, Amnesty International mengkategorikan tenaga kerja paksa oleh tentara Myanmar sebagai pelanggaran hak asasi manusia berat.

Tenaga kerja paksa bertentangan dengan Konvensi ILO nomor 29 berkaitan dengan tenaga kerja paksa dan pemerintah Myanmar sudah menerima konvensi ini pada tahun 1955. Tenaga kerja paksa juga kontradiktif dengan Universal Declarationon Human Right yang menyatakan mengenai hak asasi manusia untuk memilih pekerjaan. Sudah beberapa tahun ILO menyampaikan nota protes kepada pemerintah Myanmar mengenai tenaga kerja paksaini (International Labor Organization, 2005). Pada tahun 1999 dan 2000, rejim militer mengeluarkan 
peraturan yang melarang adanya tenaga kerja paksa ini. Namun pada kenyataannya, tentara Myanmar tetap menggunakan penduduk sipil sebagai tenaga kerja paksa.

Dari tanggal 21 hingga 23 Februari 2005, ILO Governing Body mengirimkan very High Level Team (vHLT) ke Myanmar untuk mengevaluasi pelaksanaan Konvensi ILO nomor 29 dalam undang-undang Myanmar. vHLT melaporkan penemuannya pada bulan Maret 2005 kepada ILO Governing Body mengenai tenaga kerja paksa di Myanmar. Laporan tim tersebut membenarkan dugaan penggunaan tenaga kerja paksa secara sistematis oleh tentara Myanmar. Laporan itu memberikan rekomendasi kepada pemerintahan Myanmar untuk secarat tegas melarang penggunaan tenaga kerja paksa di Myanmar. Pada bulan Maret 2005, ILO menjatuhkan resolusi kepada Myanmar bahwa ILO meminta semua negara anggota ILO untuk mempertimbangkan kembali hubungannya dengan pemerintahan Myanmar. Pada tanggal 21 April 2005 Direktur Jenderal ILO meminta semua anggota ILO mendesak pemerintahan Myanmar untuk tidak memperpanjang penggunaan tenaga kerja paksa (ALTSEAN Burma, 2006). $\mathrm{N}$ amun resolusi ILO ini tidak membawa perubahan signifikan dalam penggunaan tenaga kerja paksa di Myanmar.

Pemerintahan

Myanmar membutuhkan area geografis yang sangat luas untuk proyek-proyek sarana militer, infrastruktur dan investasi. Pemindahan paksa menjadi salah satu cara junta militer untuk menjawab kebutuhan tersebut. Sejak tahun 1989, lebih dari 500.000 orang dipaksa pindah dari rumah milik penduduk karena kawasan penduduk tersebut akan dibangun proyek-proyek pemerintah Myanmar (Smith \& Htoo, 2005). Inilah yang menjadi faktor utama gelombang pengungsi massal ke negara-negara tetangga Myanmar. Pada tahun 1991, ribuan penduduk Muslim Myanmar mengungsi ke perbatasan Bangladesh karena relokasi paksa oleh pihak junta militer dikawasan Arakan Utara (Rotberg, 2007). Masjid-masjid dilaporkan dirusak dan masyarakat sekitar dipaksa untuk membangun royek-proyek militer.

\section{International Displacement} Monitoring Centre (IDMC) melaporkan bahwa relokasi paksa terjadi di hampir sepuluh provinsi di Myanmar (Bosson, 2007). IDMC mengkategorikan relokasi paksa yang dilakukan militer Myanmar secara langsung dan tidak langsung sebagai ancaman terhadap human security karena relokasi paksa ini mengakibatkan ribuan penduduk kehilangan tempat tinggalnya dan menjadi pengungsi di daerah lain (internally displaced person).

Ashley South dari Refugees Studies Center memperkirakan 31\% penduduk Myanmar meninggalkan rumahnya karena tanah yang dimilikinya diambil oleh negara untuk tujuan tertentu (South, 2007). Hilangnya aset properti ini mengakibatkan hilangnya pendapatan penduduk Myanmar sehingga memaksa mereka untuk mencari tempat yang lebih baik. Tenaga kerja paksa juga menyebabkan penduduk meninggalkan rumahnya dan mencari daerah lain di mana tidak ada sistem tenaga kerja paksa. Human Rights Watch, pada bulan Oktober 2002, 
mempublikasikan laporan yang berjudul "My Gun was as Tall as Me: Child Soldiers in Burma". Dalam laporan tersebut dikatakan bahwa 20\% dari tentara Myanmar adalah tentara anak yang berusia di bawah 18 tahun. Dari 35.000 tentara Myanmar, 7.000 tentara diantaranya adalah anak-anak. Myanmar menjadi negara yang menggunakan tenaga kerja di bawah usia paling besar di dunia. Anak-anak diambil secara paksa oleh militer untuk menjalani pelatihan militer. Human Rights Watch memiliki bukti beberapa pemuda berumur 12 tahun yang meninggal akibat menjalani pelatihan militer yang terlalu keras. Tentara anak ini langsung dikirim melawan kelompok-kelompok pemberontak. Laporan Human Rights Watch ini diperkuat dengan laporan UNICEF pada Oktober 2002.

Tentara anak ini secara sengaja direkrut oleh tentara militer Myanmar untuk memenuhi kebutuhan pasukan militer Myanmar. Menghadapi gerakan oposisi aktivis demokrasi dan tentara pemberontakan etnik minoritas, tentara Myanmar membutuhkan pasukan tentara yang sangat besar. Namun sangat sedikit penduduk Myanmar yang mau menjadi tentara Myanmar setelah penumpasan berdarah padat ahun 1988. Tentara anak ini sebenarnya dilarang oleh undang-undang Myanmar Conscription Act 1959 yang mensyaratkan usia minimal 18 tahun untuk menjadi tentara dan sifatnya sukarela. Namun pada kenyataannya, Human Rights Watch melaporkan tentara Myanmar mengambil secara paksa anak-anak untuk menjadi anggota militer (Human Rights Watch, 2002).
Dari hasil investigasi Human Rights Watch, tentara Myanmar membuat unit khusus untuk merekrut tentara anak. Rekrutmen ini dijadikan sebagai salah satu bisnis tentara karena setiap tentara yang merekrut tentara baru maka akan mendapat imbalan uang sekitar 1-10.000 Kyat atau 15-50 kilogram beras. Untuk beberapa batalion tertentu akan mendapatkan libur dinas apabila mereka merekrut tentara baru. Tergiur oleh insentif ini, makin banyak tentara dan polisi yang mencari dan merekrut tentara anak demi mendapatkan keuntungan ini. Setelah anak-anak ini ditangkap, mereka akan dibawa ke kamp militer khusus anak-anak. Di sana mereka dilatih dan dididik untuk menjadi tentara militer. Kamp militer ini dinamakan Ye-Nyunt dengan kapasitas 50-200 orang. Calon tentara ini tidak diperbolehkan menghubungi keluarganya. Mereka juga mendapatkan pelatihan yang sangat keras dan bahkan sangat brutal.Kondisi ini membuat mereka berusaha untuk kabur. Namun apabila mereka tertangkap, mereka akan dipukuli oleh teman-temannya sendiri. Apabila tentara anak i ni sudah memiliki fisik yang kuat mereka akan dikirim ke Su Saun Yay yaitu tempat rekrutmen tentara. Setelah resmi menjadi tentara, mereka langsung dikirim ke medan pertempuran untuk melawan gerakan pemberontak (Alamgir, 1997).

Pembatalan hasil pemilihan umum tahun 1990 merupakan sebuah bukti utama pelanggaran junta militer terhadap penegakan nilai-nilai demokrasi. Setelah demonstrasi massal oleh mahasiswa pada tahun 1988 menuntut perubahan ke arah 
demokratisasi, junta militer akhirnya memutuskan menyelenggarakan Pemilu pada bulan Mei1 990. Pemilu ini diikuti lebih kurang 200 partai politik termasuk partai oposisi pimpinan Aung San Suu Kyi, The National League for Democracy (NLD). NLD kemudian dengan cepat memperoleh dukungan dari Komunitas Myanmar dan berhasil memposisikan diris ebagai partai paling popular karena mampu menggalang dukungan dari dua juta penduduk Myanmar selama masa kampanye (Luhulima, 2006).

Selama masa kampanye, junta militer melakukan serangkaian kecurangan sebelum Pemilu dilaksanakan. Para pemimpin partai oposisi ditahan oleh pihak pemerintahan. ungSan Suu Kyi ditangkap pada bulan Juli 1989. U Kyi Maung dan Utin Oo selaku pemimpin NLD juga ditahan oleh junta militer. Junta sendiri mengeluarkan berbagai peraturan yang membatasi kampanye partai oposisi. Pihak pemerintah Myanmar melarang pengumpulan massa lebih dari empat orang. Perjalanan antar kota harus dilaporkan kepada pihak pemerintah setempat. Kampanye media dikontrol sepenuhnya oleh militer. Semua universitas dan sekolah tingkat atas ditutup oleh junta militer karena dicurigai junta militer sebagai tempat berlindungnya para tokoh oposisi.

Pemilu yang diselenggarakan pada tanggal 27 Juli 1990 memenangkan NLD dengan meraih 392 dari 485 kursi pada parlemen nasional atau sekitar 82\% dari total kursi parlemen. Sementara Partai Kesatuan Nasional (National Unity Party) yang didukung penuh pemerintah junta militer hanya memperoleh 3\% kursi parlemen. Segera setelah hasil Pemilu diumumkan, junta militer membatalkan hasil Pemilu secara sepihak. Bahkan, Junta militer memenjarakan semua calon anggota parlemen hasil Pemilu dari partai NLD.

Aung San Suu Kyi dibebaskan oleh pemerintah militer pada 6 Mei 2002. Pada tanggal 30 Mei 2003, milisi pro-pemerintahan, Union Solidarity and Development Association( USDA), menyerang Aung San Suu Kyi ketika melakukan konvoi beserta pendukungnya yang mengakibatkan meninggalnya beberapa pendukung NLD. Aung San Suu Kyi serta pendukungnya pun segera dikenai tahanan rumah. Kantor pusat NLD di Rangoon ditutup. Serangan 30 Mei diklaim sebagai serangan paling kejam terhadap aktivis pejuang demokrasi setelah tragedi 1988. Staf Kedutaan Amerika Serikat yang berada di sekitar daerah penyerangan 30 Mei melaporkan bahwa penyerangan tersebut adalah sebuah kekerasan berdarah yang terencana. Laporan tersebut menyatakan bahwa sebelum penyerangan, perintah untuk menghancurkan NLD sudah diketahui oleh Komunitas. Senjata-senjata pun sudah dipersiapkan. Laporan ini menunjuk Than Shwe, jenderal senior yang merangkap ketua USDA sebagai aktor utama yang bertanggungjawab terhadap penyerangan 30 Mei.

\section{Perdebatan Nilai dan Implikasi terhadap Kebijakan Luar Negeri}

Tertulis dalam konstitusi bahwa Uni Eropa dan Amerika Serikat harus memperjuangkan nilai demokrasi dan HAM dalam kebijakan luar negerinya. Setengah dari sanksi yang dijatuhkan 
Uni Eropa adalah terkait pelanggaran HAM. Dalam kasus Myanmar, Uni Eropa menjatuhkan sanksi kepada Myanmar sejak tahun 1996 berupa larangan masuk bagi pejabar militer ke wilayah Uni Eropa. Sanksi ini terus bertambah dengan memasukkan embargo senjata, larangan investasi dan pembekuan asset pejabat militer Myanmar. Selain itu, Amnesty International dan Human Rights Watch menjadi OMS yang sangat agresif mengkampanyekan pelaksanaan nilai HAM dalam politik Myanmar. Mereka mendorong Uni Eropa dan Amerika Serikat untuk konsisten menjatuhkan sanksi kepada Myanmar.

Bagi ASEAN, Myanmar menjadi masalah yang rumit. Nilai HAM bukan menjadi agenda prioritas bagi negara anggota ASEAN dan mereka lebih mengutamakan stabilitas keamanan dan ekonomi. Beberapa negara ASEAN masih dipimpin oleh kalangan militer dan tidak menggunakan cara yang demokratis. Indonesia dipimpin oleh Suharto, Malaysia dipimpin oleh Mahathir Muhammad dan Singapura dipimpin oleh Lee Kuan Yew. Alih-alih mempromosikan HAM dan demokrasi, Indonesia, Malaysia dan Singapura mengajukan 'ASEAN Way' dimana masalah internal sebuah negara harus diselesaikan oleh negara tersebut dan penyelesaian masalah kawasan dengan metode konsensus dan informal. 'ASEAN Way' adalah sebuah indikator perlawanan dari negara-negara Asia Tenggara terhadap hegemoni nilai HAM dan demokrasi. Bagi kelompok kritis terhadap HAM, mereka melihat bahwa pemberlakuan HAM merupakan penindasan terhadap nilai-nilai lokal seperti musyawarah dan konsensus.
Selain itu, kelompok ini mengatakan bahwa negara-negara Asia lebih menganggap kesejahteraan ekonomi lebih penting dari hak-hak sipil politik. Hak-hak sipil politik masyarakat dapat dibiarkan demi mengejar pertumbuhan ekonomi. Demonstrasi dan perdebatan hanya akan memperlambat kesejahteraan ekonomi negara.

Perdebatan kedua nilai - hak asasi manusia dan ASEAN Way tercermin di dalam perdebatan di dalam ASEM (Asia Europe Meeting). Uni Eropa menginginkan Myanmar tidak berpartisipasi dalam ASEM atas pertimbangan HAM dan ASEAN menolak kebijakan diskriminatif tersebut. ASEAN berpendapat bahwa Uni Eropa harus mengikuti normanorma-norma yang disepakati negaranegara ASEAN dan ARF (Asia Regional Forum). Pada awalnya Menteri luar negeri Eropa setuju terhadap pendekatan ini namun sikap tersebut berubah setelah Myanmar diterima sebagai negara anggota ASEAN. The Joint Declaration of the 12th ASEAN-EU Ministerial Meeting pada tahun 1997 di Singapura menekankan bahwa kerjasama keamanan harus memperdalam isu-isu yang menjadi perhatian bersama dan dialog tidak seharusnya berhenti karena perbedaan dalam hal-hal tertentu. Namun perbedaan nilai menjadi faktor utama kegagalan untuk mencapai kesepakatan dan menyebabkan pembatalan pertemuan Komite Kerjasama Bersama tahun 1997. Pertemuan ASEM II di London 1998 juga mengalami kebuntuan. Karena Inggris tidak memberikan visa bagi para pejabat Myanmar, pemimpin ASEAN mengancam untuk melakukan 
boikot. Uni Eropa melihat ASEM lebih dari sekedar forum ekonomi dan segala masalah politik ekonomi harus ditangani pada tingkat menteri. Upaya untuk menyingkirkan Myanmar dari ASEM gagal. Dan meskipun para pejabat dari junta militer tidak menghadiri pertemuan tersebut, disepakati bahwa pada proses ASEM akan menjadi forum informal di mana semua peserta akan memiliki status yang sama. Dalam sebuah pernyataan yang disampaikan Ketua untuk pertemuan ASEM II, ASEM tidak perlu dilembagakan dan merupakan proses informal. Agar hubungan ASEAN - Uni Eropa tidak disandera oleh protes Uni Eropa terhadap pelanggaran HAM di Myanmar, pertemuan Menteri Luar Negeri Uni Eropa dan ASEAN dan perwakilan Myanmar diselenggarakan di Vientiane, Laos pada bulan Desember 2000. Namun beberapa anggota Uni Eropa hanya mengirim delegasi dengan status diplomatik rendah. Deklarasi dibuat dengan mempertimbangkan semua nilai yang ASEAN dan Uni Eropa. Meskipun demikian, perwakilan Myanmar masih ditolak aksesnya untuk menghadiri Perjanjian Kerjasama Ekonomi ASEAN-Uni Eropa sehingga Myanmar tidak dilibatkan dalam program-program pembangunan.

Kebuntuan dalam proses ASEM juga koheren dalam hubungan ASEANUni Eropa. Dengan tidak adanya niat baik dari junta, dua pertemuan tingkat menteri ASEM dibatalkan (Juli dan September 2004). Uni Eropa menegaskan sikap untuk menolak keanggotaan Myanmar selama beberapa syarat terpenuhi seperti pembebasan Aung San Suu Kyi, partisipasi bebas dari Liga Nasional untuk Demokrasi dan wakil-wakil terpilih lainnya dalam Konvensi Nasional (Rocher, 2012).

\begin{tabular}{|c|c|}
\hline Masalah & Myanmar \\
\hline epada & kerjasama \\
\hline
\end{tabular}
Eropa. Negara-negara Asia Tenggara telah berhasil dalam menembus pasar Uni Eropa dan melakukan diversifikasi komposisi ekspor mereka ke Uni Eropa. Pada akhir tahun 1999, nilai perdagangan ASEAN dengan Uni Eropa melampaui nilai perdagangan Uni Eropa dengan 70 negara ACP (Afrika, Karibia, dan Pasifik) (Kettunen, 2004). Sebelum krisis keuangan Asia tahun 1997, Uni Eropa menikmati perdagangan surplus ASEAN hanya pada tahun 1985 dan 1995. Pada tahun 1998, surplus yang dinikmati ASEAN hampir sepuluh kali lipat dari level tahun 1997 Pada tahun 2005, ekspor Uni Eropa ke ASEAN sebesar EUR 44.888 miliar, tetapi impornya dari ASEAN mencapai EUR 70.520 miliar meninggalkan defisit perdagangan sebesar EUR 25.632 miliar. Defisit ratarata 2001-2005 adalah EUR 25 miliar (Europe-Asia Centre, 2006). Oleh karena itu, ketika pada tahun 2002-2003, beberapa anggota ASEAN meminta negosiasi FTA dan Komisi Eropa menolak proposal tersebut. Komisi Eropa mengklaim bahwa kriteria ekonomi, seperti potensi pasar dan perlindungan terhadap kepentingan ekspor Uni Eropa, bukan satu-satunya kriteria untuk memilih mitra FTA. Kriteria Politik - catatan hak asasi manusia dan demokrasi kredensial juga diperhitungkan (Robles, 2008). Seperti sudah bisa diduga, ASEAN tetap menolak untuk mengambil tindakan terhadap Myanmar bersikeras untuk 
menggunakan negosiasi region-to-region sebagai sarana meningkatkan posisi tawar ASEAN. Apabila Uni Eropa menolak Myanmar maka Uni Eropa harus menolak kerjasama dengan seluruh negara anggota ASEAN. Alternatif untuk posisi ASEAN akan mensyaratkan baik bernegosiasi dengan anggota ASEAN masing-masing, yang pasti tidak dapat diterima ke ASEAN, atau tidak masuk ke dalam FTA, yang akan menjadi tidak dapat diterima untuk kedua (Nation, 2007). Pada bulan Juli 2006, Penasihat Perdagangan Uni Eropa di Thailand mengakui bahwa reformasi politik di Myanmar adalah masalah utama dalam hubungan ekonomi perdagangan Uni Eropa dan ASEAN.

\section{Kemenangan Constructive Engagement?}

Badai Nargis (Cyclonic Storm
Nargis) ialah sebuah badai
tropis kencang yang bertemu daratan
di Myanmar pada tanggal 2 Mei 2008,
mengakibatkan bencana kemusnahan
dan menyebabkan 85.000 nyawa
meninggal dan 53000 penduduk hilang
(International Federation of Red Cross
and Red Crescent Societies, 2008).
Mitigasi dampak badai taifun ini menjadi bukti bagaimana negara-negara ASEAN mendapat kepercayaaan dari Myanmar. Bantuan yang ingin disampaikan oleh negara-negara maju tidak dapat dikirimkan ke Myanmar karena akses ditolak oleh Pemerintah Myanmar. ASEAN, PBB dan Pemerintah Myanmar membentuk Tripartit Core Group yang bertugas mengatur distribusi logistik. Sikap Myanmar ini membuktikan bahwa kedaulatan negara menjadi sangat penting bagi Myanmar dan berbagai tindakan intervensi
Amerika Serikat dan Uni Eropa telah menjadikan Myanmar sebagai sebuah target korban. Penolakan akses ini adalah sebuah tindakan balas dendam Myanmar atas kebijakan sanksi yang dilakukan Uni Eropa dan Amerika Serikat. Badai Nargis menjadi bahan koreksi bagi AS dan Eropa dalam tindakan sanksi mereka. Berbagai sanksi yang diberikan gagal dalam mengubah sikap dan perilaku Myanmar. Sanksi yang diharapkan mengkonvergensi sikap Myanmar tidak berhasil dan Myanmar bertahan dengan prinsip kedaulatannya. Sebaliknya upaya yang dilakukan ASEAN melalui constructive engagement berhasil meraih kepercayaan dari Myanmar untuk melakukan rekonsiliasi dan demokratisasi di Myanmar. Myanmar secara resmi meminta bantuan dari Indonesia dalam membantu demokratisasi dan rekonsiliasi di Myanmar.

Keberhasilan ASEAN tidak lepas dari strategi non-konfrontasi dan strategi jangka panjang. Bali Democracy Forum menjadi sebuah contoh bagaimana Indonesia menggunakan teknik dialog dalam memperkenalkan HAM dan demokrasi. Penggunaan diplomasi dialog antar pejabat pemerintah dan bantuan teknis menjadi pemikat Myanmar untuk berkonsultasi dengan ASEAN. Apakah ASEAN dan Uni Eropa adalah aktor solidaris dengan cara yang berbeda? Atau nilai HAM dan demokrasi hanya sebagai samaran bagi ASEAN untuk tetap bekerjasama dengan Uni Eropa?

\section{Kesimpulan}

Globalisasi adalah sebuah fenomena yang membuka ruang sekat yang selama ini membatasi komunikasi 
manusia. Globalisasi memungkinkan masyarakat yang berada di belahan dunia yang berbeda saling berinteraksi tanpa batasan waktu dan biaya. Fenomena ini membawa perubahan yang signifikan termasuk dalam penyebaran nilai HAM dan demokrasi. Globalisasi dianggap sebagai Amerikanisasi ketika berbagai negara mulai menganut sistem demokrasi. HAM menjadi nilai universal dan harus dipatuhi oleh berbagai masyarakat di seluruh dunia. Kemunculan aktivis HAM dan OMS menjadi tanda bagaimana nilai-nilai HAM menjadi sangat sakral dan penting dalam hubungan internasional.

Namun menggunakan studi kasus Myanmar, penyebaran nilai HAM ini menimbulkan resistensi. Sanksi yang dijatuhkan Uni Eropa dan Amerika Serikat menjad bukti bahwa nilai HAM harus disebarkan ke berbagai belahan dunia. Namun penyebaran nilai HAM ini mendapat reaksi negatif dari negaranegara ASEAN. ASEAN Way menjadi simbol perlawanan dengan pertumbuhan ekonomi dan kesejahteraan masyarakat menjadi prioritas negara. Kebijakan sanksi yang dilakukan AS dan Uni Eropa pun mendapat reaksi negatif dari ASEAN ketika bencana Siklon Nargis terjadi. Myanmar secara tegas menolak bantuan dari Uni Eropa dan Amerika Serikat dan bekerjasama dengan ASEAN dan PBB dalam mendistribusikan bantuan kepada warga Myanmar.

HAM dan demokrasi terbantahkan menjadi nilai universal dan kedaulatan negara tetap menjadi tolak ukur tatanan internasional. Keberadaan OMS yang mengadvokasi sanksi bagi Myanmar justru menciptakan ketidakharmonisan dalam interaksi negara. Sesuai dengan konsep pluralis, tatanan internasional dibangun dengan negara sebagai aktor dan penggunaan diplomasi sebagai solusi masalah. Struktur internasional yang menggunakan konsep intervensi tidak dapat berlaku di Asia Tenggara. Hak negara dalam mengelola masalah domestik tidak boleh diabaikan dan diganggu. Apabila muncul masalah domestik yang menjadi perhatian masyarakat internasional maka diplomasi menjadi solusi penyelesaian masalah tersebut. Siklon Nargis membuktikan bahwa tatanan internasional hadir meskipun dalam struktur internasional yang bersifat anarki.

Oleh karena itu, artikel ini berkesimpulan bahwa pemikiran pluralis cocok untuk digunakan dalam melihat interaksi negara di kawasan Asia Tenggara. Pemikiran Bull yang menekankan coexistence sangat relevan dalam melihat dinamika Asia Tenggara. Kawasan ini memiliki banyak masalah yang harus melibatkan negara lain di dalam penyelesaiannya seperti masalah HAM, lingkungan hidup atau pembangunan organisasi regional. Interaksi yang terjadi bersifat damai dengan mengakomodasi perbedaan yang dimiliki oleh negara ASEAN. Kawasan ini memiliki tingkat keragaman yang sangat tinggi baik dalam budaya, agama, dan tingkat kesejahteraan ekonomi. Menariknya, perbedaan ini tidak menjadi sumber masalah utama di kawasan ini. Perbedaan ini dapat dikelola dengan prinsip coexistence yang menekankan dialog dan komunikasi antar masyarakat. 


\section{Daftar Rujukan}

Alamgir, J., 1997. Against the Current: the Survival of Authoritarianism in Burma. Pacific Affairs, 70(3), pp. 333-350.

ALTSEAN Burma, 2006. Forced Labor in Burma: Time for Action, Bangkok: s.n.

Amnesty International, 2005. Leaving Home, London: s.n.

Amnesty International, 2005. Myanmar's Political Prisoners: A Growing Legacy of Injustice, London: Amnesty International.

Bosson, A., 2007. Forced Migration/Internal Displacement in Burma, Jenewa: s.n.

Bull, H., 1966. Grotian Conception on International Society. In: Diplomatic Investigation: Essays in the Theory of International Politics. Michigan: Allen \& Unwin, pp. 51-73.

Bull, H., 1977. The Anarchical Society: A Study of Order in World Politics. Basingstoke: Palgrave.

Buzan, B., 2004. From International to World Society: English School Theory and the Social Structure of Globalisation. Cambridge: Cambridge University Press.

Europe-Asia Centre, 2006. A Qualitative Analysis of a Potential Free Trade Agreement between the EU and ASEAN. A Report prepared for the European Commission and the EU-ASEAN Vision Group. Limerick and Paris: Europe-Asia Centre, University of Limerick-IFRI.

Human Rights Watch, 1990. World Report 1990, Jakarta: s.n.

Human Rights Watch, 2001. Burma Still Using Forced Labor. [Online] Available at: http://www.hrw.org/en/news/2001/06/11/burma-still-usingforced-labor

Human Rights Watch, 2002. A Gun as Tall as Me: Child Soldier in Burma, Brussels: Human Rights Watch.

Human Rights Watch, 2002. A Gun as Tall as Me: Child Soldier in Burma, Brussels: Human Rights Watch.

International Federation of Red Cross and Red Crescent Societies, 2008. Myanmar: Cyclone Nargis 2008 Facts and Figures, Geneve: International Federation of Red Cross and Red Crescent Societies.

International Labor Organization, 2005. Developments concerning the question of the Observance by the Government of Myanmar of the Forced Labor Convention, 1930 (No. 29), Jenewa: s.n.

Kettunen, E., 2004. Regionalism and the Geography of Trade Policies in EU-ASEAN Trade. Helsinki: Helsinki School of Economics. 
Luhulima, C., 2006. Perimbangan Kekuatan di Myanmar, Faktor ASEAN dan Kepentingan Indonesia. Analisis CSIS, 35(2), pp. 160-172.

Nation, T., 2007. FTA with EU may cut Burma out. [Online] Available http://nationmultimedia.com/2007/02/09/business/business_30026366.php [Accessed 13 February 2013].

Parliament, E., 2007. Resolution on Burma. [Online] Available at: http:// www.europarl.europa.eu/oeil/popups/ficheprocedure.do?id=553326 [Accessed 13 February 2013].

Percy, K., 2015. More Burma protesters arrested as curfew orders ignored. [Online] Available at: http://www.abc.net.au/news/2007-09-28/more-burmaprotesters-arrested-as-curfew-orders/684316 [Accessed 10 June 2015].

Petersson, M., 2006. Myanmar in EU-ASEAN Relation. Asia Europe Journal, Volume 4, pp. 563-581.

Robles, A., 2008. An EU-ASEAN FTA: The EU's Failures as an International Actor. European Foreign Affairs Review, Volume 13, pp. 541-560.

Rocher, S. B. d., 2012. The European Union, Burma/Myanmar and ASEAN : A challenge to European norms and values or new opportunity?. Asia Europe Journal, Volume 10, pp. 165-180.

Rotberg, R. I., 2007. Worst of the Worst: Dealing with Repressive and Rogue Nations. Washington, D.C: Brookings Institution Press.

Smith, M. \& Htoo, N., 2005. Another Snake in the Jungle? Shwe Gas Development in Western Burma, Washington: s.n.

Smith, M. \& Htoo, N., 2006. Gas Politics: Shwe Gas Development in Burma, Washington: s.n.

South, A., 2007. Burma: The Changing Nature of Displacement Crises, Oxford: s.n.

Thomson, C. N., 1995. Political Stability and Minority Groups in Burma. Geographical Review, 85(3), pp. 269-285.

Wheeler, N., 2000. Saving Strangers: Humanitarian Intervention in International Society. Oxford: Oxford University Press. 